\title{
Adenosine Receptor A2a
}

National Cancer Institute

\section{Source}

National Cancer Institute. Adenosine Receptor A2a. NCI Thesaurus. Code C38612.

Adenosine receptor A2a (412 aa, $45 \mathrm{kDa}$ ) is encoded by the human ADORA2A gene.

This protein plays a role in $\mathrm{G}$ protein-coupled receptor signaling, phagocytosis, blood circulation, inflammatory response, sensory perception and central nervous system development 